\title{
Three decades of pastoralist settlement dynamics in the Ethiopian Omo Delta based on remote sensing data
}

\author{
${\text { Samira } \text { Amos }^{1} \text { (D) Sileshi Mengistu }}^{2} \cdot$ Fritz Kleinschroth $^{1}$ D
}

Received: 28 November 2020 / Accepted: 18 August 2021 / Published online: 7 October 2021

(c) The Author(s) 2021

\begin{abstract}
River deltas provide important livelihoods to local populations, but at the same time are under increasing anthropogenic pressure. The opening of the Gibe III dam on the Omo River in Ethiopia in 2016 attracted international attention due to the importance of the free-flowing River for pastoralist communities in the Omo Delta. Sustainable river basin management requires spatially explicit, long-term information about human settlements to mitigate negative impacts on people's livelihoods. Based on remote sensing time-series, and supplemented with ground-truthing, we mapped settlement-dynamics of the pastoralist Dasanech tribe. The inhabited area more than doubled from 1992 to 2009. From 2009 to 2019, settlements became more permanent and concentrated in the North of the Delta. Our results indicate that the Omo Delta has overall gained in importance as a livelihood area, but that the livelihoods of the traditionally nomadic people are shifting in the context of increasing investment in infrastructure. Management of future river flow at dams should consider the location and the trajectory of change in downstream settlements.
\end{abstract}

Keywords Lake Turkana Indigenous peoples · Villagization · Sustainable development · Water-energy-food nexus · Remote sensing · Ground-truthing · Dasenech settlement dynamics · Gibe III Dam · Omo River · Ethiopia

\section{Introduction}

In large parts of the world, wetlands support local populations due to their high productivity, but at the same time are under increasing anthropogenic pressures (Mitchell 2013). This applies particularly to Africa, where many people directly depend on wetlands for subsistence livelihoods such as agriculture and fishing (Adams 1993; Mitchell 2013). River deltas provide important resources for local communities but are often highly degraded (Syvitski et al. 2009; Tessler et al. 2015). One important driver of delta degradation is lack of river dynamics and sedimentation resulting from upstream river modifications such as dams, with implications for the ecology and the livelihoods of those who depend on ecosystem goods and services (Syvitski et al. 2009). Large hydroelectric dams provide electricity and

Samira Amos

samira.amos@usys.ethz.ch

1 Ecosystem Management Group, Department of Environmental Systems Science, ETH Zurich,

Universitätsstr. 16, 8050 Zürich, Switzerland

2 South Omo Research Center, Jinka, Ethiopia provide new opportunities for economic development, but their environmental and social sustainability is increasingly being questioned (Khagram 2004; Riethof 2017; Schapper et al. 2019). A major debate over dam projects and the associated water-energy-food security nexus is ongoing globally (Khagram 2004; Müller-Mahn and Gebreyes 2019).

Ethiopia has the highest hydropower capacity in Africa (International Hydropower Association 2020), pursuing a "Climate-Resilient Green Economy" strategy (FDRoE 2011). The Gilgel-Gibe III dam (hereafter "Gibe III") on the Omo River, opened in 2016, is a major component of this strategy: it has doubled Ethiopia's installed electricity capacity and will enable the irrigation of large-scale agriculture schemes downstream (FDRoE 2011; Hodbod et al. 2019a). The construction of the dam attracted international attention due to the importance of the free-flowing River for the livelihood of downstream pastoralist communities (Human Rights Watch 2012; International Rivers 2020; Turton 2018). The Omo Delta in Lake Turkana is home to the indigenous Dasanech people, and is particularly important for their livelihoods as it provides water, sediment, and nutrients for flood-recession agriculture and grazing throughout the year in an otherwise semi-arid region (Carr 2017a; Yntiso 2012). 
Traditionally nomadic, the villages of the Dasanech oscillate in appearance, number, and size over the course of the year (Carr 2017b). During and shortly after the wet season, households bring their herds to graze on fresh grass, herbs and shrubs on the wide plains (Carr 2017b). During the dry season, they return to settlement areas with continuous water supply from the Omo River for cattle grazing and agriculture (GoE and EEPC 2009) and only the young men move with the cattle in search of pasture. The occurrence of seasonal floods decreased substantially after the opening of Gibe III (Hodbod et al. 2019a; Tebbs et al. 2019). From completion of the dam in 2015, rainwater from the highlands (Gibe and Gojeb catchments) is first collected in the reservoir and then released continuously through the hydropower turbines, and flooding is controlled by dam releases, in combination with rainfall in the remaining catchment below the dam. In parallel, villagization programs have been initiated by the government to encourage pastoralist communities in the South Omo Zone towards permanent settlement, partly replacing their lost livelihoods through irrigation programs (Kamski 2016; Pastoralist Areas Department 2004).

Sustainable development requires weighing the costs and benefits of dam projects and implementing appropriate compensation measures, such as artificial flooding (Adams 1993). This requires an understanding of the needs of downstream pastoralist communities and their resilience to induced changes (Hodbod et al. 2019a). Such an understanding can be gained through, for example, the collection of reliable data and by taking a more participatory approach to decision-making. Indigenous peoples are often neglected in decision-making processes, partly due to the lack of spatially explicit information of their settlements (Chapin et al. 2005), as is the case for the pastoralists in Ethiopia's South Omo Zone, whose livelihoods are impacted by Gibe III. The Dasanech are at the same time vulnerable to and dependent on recurrent floods due to their settlement in the low plains of the Omo Valley and their reliance on the Delta ecosystem. Settlements in the Omo Delta are particularly difficult to assess because of the complex and spatially fluctuating environment (Haack 1996). Visual interpretation of remote sensing imagery presents an opportunity to assess long-term settlement changes of pastoralist peoples in such remote and dynamic environments, providing reliable data covering a long time period at a scale that may not be achievable with field work (Deleu et al. 2015; Fox et al. 2019; Sanyal and Lu 2005).

Spatially explicit data on river settlements provide an important base for river basin management strategies. Such strategies could include controlled environmental flow releases at dams to meet the needs of downstream communities and environments (Adams 1993; Hoang et al. 2018; Syvitski et al. 2009), and must draw on a good understanding of downstream human population distributions, land uses, and resource needs. The most important goal for decisionmaking processes is to empower marginalized people and to achieve free, prior, and informed consent to implementation of environmental policies. Our remote-sensing-based approach to understand pastoralist settlement dynamics in the Delta is no substitute for participatory decision-making processes, but rather designed to support or even initiate such a process by putting people on the map. To this end, we used space-borne remote sensing together with GIS to examine pastoralist settlement dynamics in the most populated part of the Omo Delta in Ethiopia over three decades, addressing the following questions: (1) How have pastoralist settlements in the Delta changed in extent and persistence during the last three decades? And (2) how have settlements changed structurally during the construction, filling, and operation of the Gibe III dam?

\section{Methods}

\section{Study area}

We investigated settlement dynamics in the Omo Delta within the Dasanech woreda, Southern Nations, Nationalities and Peoples Region of Ethiopia. The study area is a section of approximately $620 \mathrm{~km}^{2}$ including the Delta's two major Omo River branches downstream of Omorate (Fig. 1). We chose the study area as the most densely populated section of the Delta, with most people members of the Dasanech tribe (Carr 1977; PCC 2007).

Overall, the region is semi-arid with high seasonal rainfall from February to September and frequent prolonged drought (GoE and EEPC 2009; Jaweso et al. 2019). By the end of the rainy season, parts of the Delta area are flooded by the Omo River (Hathaway 2009), the principal stream of the hydrologically closed Turkana basin, supplying more than $80 \%$ of the inflow to Lake Turkana (Velpuri and Senay 2012). Consequently, changes in the River's water and sediment flux affect Lake Turkana and ultimately the extent of the Omo Delta and its ecosystem, with implications for local livelihoods (Getahun et al. 2020; Haack 1996; Tebbs et al. 2019).

The Omo-Gibe basin is of major interest to the Ethiopian government for hydropower generation, villagization projects, and the construction of irrigated agriculture schemes. Both the Gibe III and Koysha dams, the latter still under construction, are an important component of the government's development strategy (GoE and EEPC 2009; Pastoralist Areas Department 2004). Gibe III is located about $400 \mathrm{~km}$ upstream from the Delta. The filling and operation of Gibe III led to a substantial decrease in the frequency of Omo River floods and amount of sediment flux (Hodbod et al. 2019a), and to a decrease in Lake 

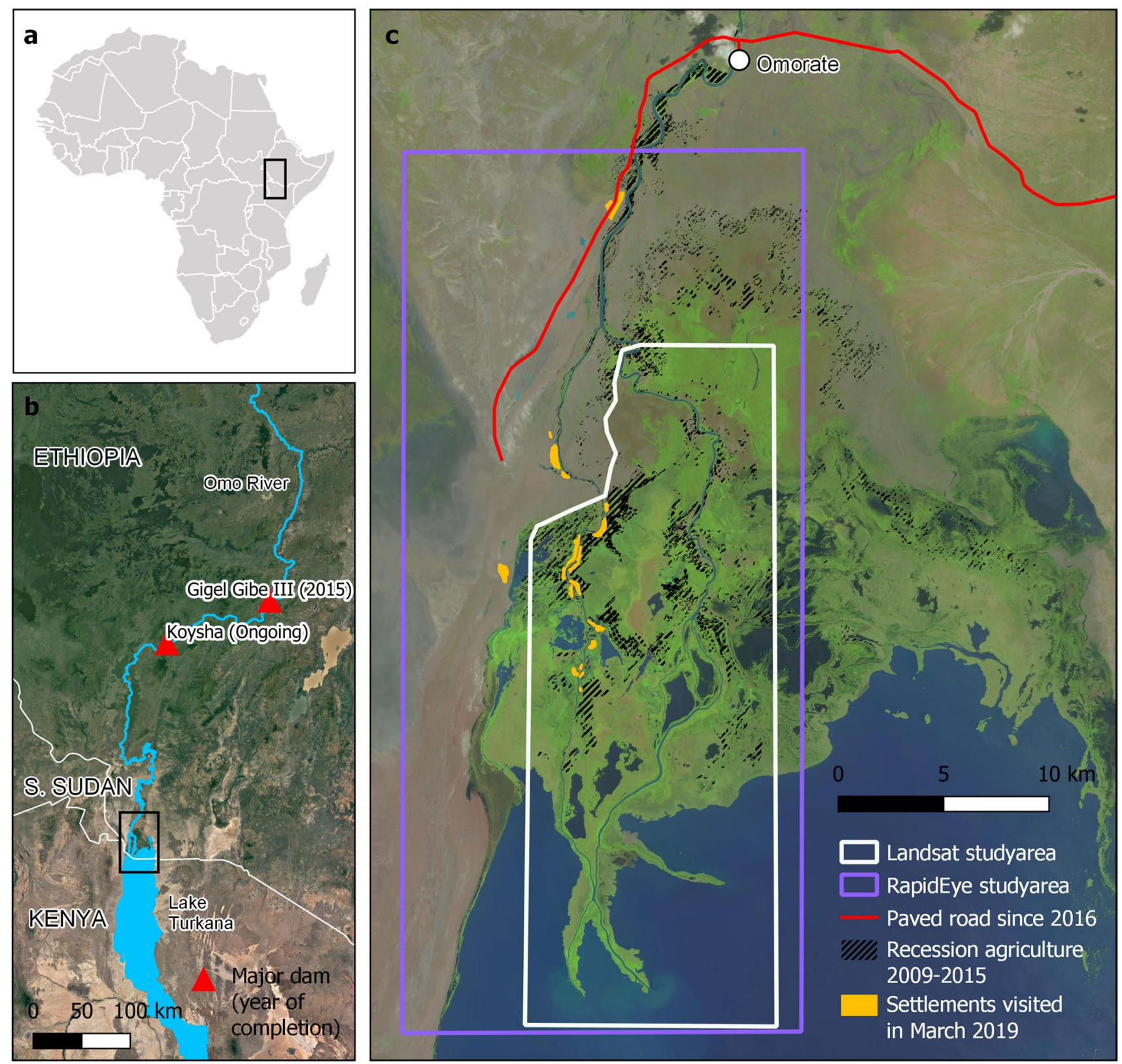

Fig. 1 Overview of (a) the location of the study area on the African continent, (b) the river modifications of the Omo River (Background Landsat) and (c) the extent of the analysed time series based on Land-

Turkana's annual water level oscillations (Gownaris et al. 2017). The reduction of environmental dynamics in the Delta is drastic and its consequences have yet to become fully understood (Avery and Tebbs 2018). Apparent consequences with implications for the food security of pastoralist populations include desiccation of the Delta, loss of fisheries livelihoods, and loss of forests (Hodbod et al. 2019a). Related large-scale irrigation agriculture projects are expected to further reduce the water flux of the Omo River (Avery and Tebbs 2018; Kamski 2016), although sat (white box) and RapidEye satellite imagery (purple box) with main areas for flood-recession agriculture (Semeria 2020)

their implementation has fallen behind schedule (Kamski 2019).

\section{Remote sensing imagery and data}

Satellite data have significant high potential for monitoring socioeconomic developments at low cost (Watmough et al. 2019). Remote sensing, combined with GIS-based analyses, is increasingly used to assess sedentary as well as mobile settlements in rural areas (Deleu et al. 2015; Fox et al. 2019; 
Sanyal and Lu 2005; Wild et al. 2019). We manually mapped settlements based on Landsat 5, 7, 8, RapidEye Ortho and Sentinel-2 images (U.S. Geological Survey 2019; Planet Team 2017; EEA 2019). We conducted two independent remote sensing analyses adapted to the spatial and temporal resolution of the different datasets and the research questions. Firstly, for the "Landsat study" we used Landsat data from 1992 to 2019 to track land that is settled by pastoralists (hereafter "inhabited") within the evergreen part of the Delta. Despite Landsat's comparably low resolution (30 m), the imagery allows the identification of general land use trends and, based on this, an estimation of inhabited areas (Dwivedi et al. 2005). Secondly, for the "RapidEye study" the higher spatial resolution of the RapidEye Ortho (5 m) and Sentinel-2 $(10 \mathrm{~m})$ images allowed the detailed identification of settlements as well as infrastructure in the Delta during a shorter period from 2009 to 2019 (Deleu et al. 2015). We ran these two different analyses in parallel to assess the ongoing developments independently. The remote location, cloudy conditions during rainy season, and malfunction of the Landsat 7 satellite (NASA 2019) limit the available data. For this reason, we only included images from 1992 onwards and had to be flexible with the capture date of the images. For analysis, we therefore grouped available images in two-year intervals. Moreover, in the RapidEye study we only considered images taken during the dry season with the exceptions of 2013 and 2019, where we additionally included wet season images for comparison. In order to highlight contrasting settlement attributes, we used different band combinations for colour composites (band combination for Landsat 4,5 and 7: 7-4-2 and 7-5-3; Landsat 8: 7-5-3 and 7-6-4; RapidEye Ortho: 5-4-2 and 4-3-2; Senitel-2: 4-3-2). Additionally, we used high-resolution imagery provided by Google Earth and Bing as a reference. For ground-truthing, we conducted a field visit in March 2019, when we followed the western stem of the Omo River from Omorate into Lake Turkana by boat (see locations in Fig. 1).

\section{Data collection and analysis}

With the Landsat study we produced an overall analysis of settlement patterns from 1992 to 2019, covering the total area, persistence, and location of inhabited land. With the RapidEye study we examined pastoralist settlement and infrastructure change from 2009 to 2019 (during the construction, filling, and operation of the Gibe III dam) in more detail, covering the total area and location of settlements; and additionally changes in the houses' building material and the road network (for further information on data analysis and the accuracy assessment see Online Resource 1 in the electronic supplementary material).

We did not find any reliable automated classification process for pastoralist settlements and therefore manually digitized settlements using QGIS (QGIS Development Team 2018) (Fig. 2). For the Landsat study, the mapped polygons represent inhabited land, which includes both settlements and the adjacent utilized land, and is therefore comprised of a mosaic of houses, animal shelters, and smaller patches of cultivated land. While individual traditional houses (hereafter "huts") of the Dasanech are not visible on Landsat imagery, inhabited areas are typically kept free from vegetation by humans and livestock and consequently show a distinct spectral signature in contrast to the dense surrounding vegetation. Accordingly, this classification approach is not feasible in the desert areas that dominate the landscape outside the Delta. We therefore restricted the study area to the evergreen areas of the Delta (approximately $280 \mathrm{~km}^{2}$, Fig. 1). We classified bare land as inhabited if it contrasts clearly with its surroundings, exhibits a detectable size of more than three Landsat pixels (approximately $1^{\prime} 800 \mathrm{~m}^{2}$ ) and if the area was reasonably homogenous. The detection might be affected by the rate of vegetation recovery after people leave. However, we could observe in our year-by-year analysis that vegetation regrows quickly in the Omo Delta as long as water from the River and the Lake is available. In cases of uncertainty, we consulted validation sources (data from our field visit and comparison with high-resolution reference) to decide whether the area under consideration is possibly inhabited.

For the RapidEye study, the mapped polygons represent settlements. Identified settlements include semi-permanent settlements consisting of traditional as well as tin-roofed houses, but also cattle camps and temporary scattered settlements. We carried out the mapping by looking for characteristic features that most settlements have in common, namely the round huts (visible as points of different shades on the imagery) and the fences of grazing grounds (circular lines). We did not include military or administrative facilities (consisting solely of tin-roofed houses in distinct arrangements) and cultivation area. For analysis, we divided the data in two groups: settlements within the evergreen areas inside the Delta and settlements within the desert areas further north. The evergreen areas of the Delta were determined by a leaf area index map based on a Sentinel-2 image of March 2018 (made available by VISTA Remote Sensing in Geosciences, Munich). The RapidEye study included the manual digitalization of points based on the occurrence of tin-roofed houses. Tin-roofed houses contrast with the huts due to different building material and architecture (Fig. 3). Traditionally, the Dasanech live in huts mostly made from natural materials (Carr 1977). However, more permanent Dasanech settlements use sheet metal as a component for their huts. Therefore, we have mapped the houses on the basis of their tin roofs (which can be recognized by the reflection of sunlight), also taking into account their rectangular shape and location. We further used RapidEye imagery to identify the 
Fig. 2 Example for Landsat and RapidEye study of rainy season 2013. (a1) Google Earth image of July 2013 as reference for detection of settlements and inhabited area, (a2) mapped settlement area on RapidEye Ortho NIRimage of August 2013, (a3) mapped inhabited area on Landsat 8 false colour image of July 2013 and (b1) Google Earth image of July 2013 as reference for detection of tin-roof houses, (b2) tagged tin-roof houses on RapidEye Ortho NIR image of August 2013

Fig. 3 (a, b) Dasanech villages, (c) tin-roof house in the South Omo Zone (own images)
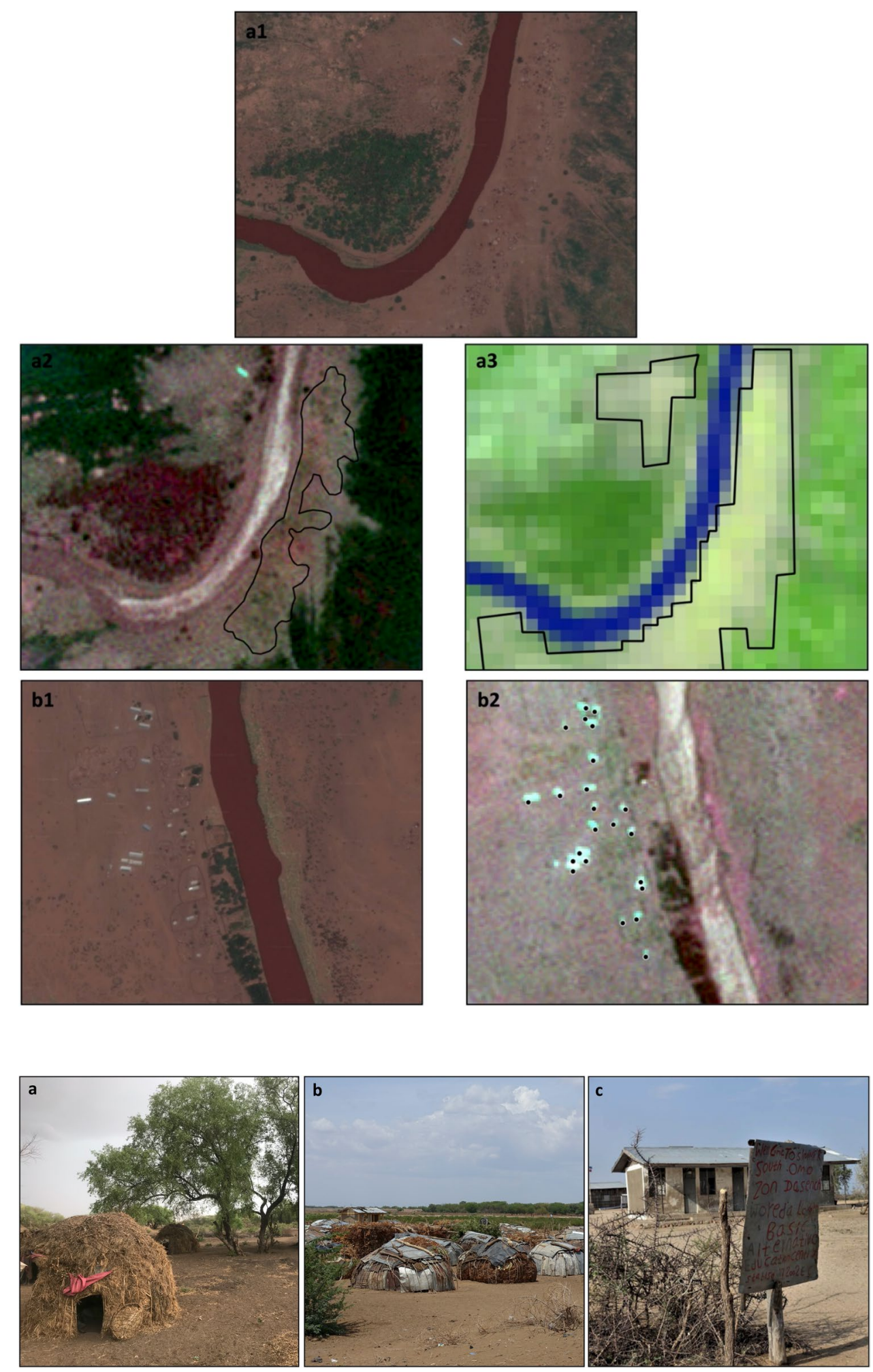

To get an idea of how many people are resident in the

location and timing of the construction of a new paved road leading from a newly constructed bridge in Omorate to the former site of Fort Wilkinson, which now serves as a military post in the border region between Ethiopia, Kenya, and South Sudan (Fig. 1).
Delta, the RapidEye study includes an estimate of the population density in 2009. We estimate the population density in 2009 because the most complete high resolution satellite imagery (provided by Bing maps) was captured in that year. 
The estimate is extrapolated from the expected number of huts in the Delta in 2009, assuming that on average five people are living in each hut (Carr 1977; Micheli 2020; PCC 2007). We calculated the expected number of huts by multiplying the RapidEye settlement area in 2009 by the mean density of huts per settlement. The population estimate is based on assumptions from older references and therefore has limitations for the interpretation of the current situation (for detailed methods see Online Resource 1).

This study is based on remote sensing, which has two main limitations. First, many aspects of social life and human interactions are not detectable. For example, people's needs and values, and how these change over time, cannot be assessed remotely. Satellite-based sensors do not detect individual persons and for privacy reasons we never intended to do so. Remote sensing technology can therefore not replace, but only complement field-based studies. Second, even within the range of detectable features such as settlements, a major challenge for remote sensing time series is the variability of the imagery due to weather, capture time, sun elevation, and seasonal variations. Additionally, due to the manual digitalization, the data may include a potential observer bias. We approximated the uncertainty in the data through three approaches: First, we compared the settlements (RapidEye study) to the inhabited area (Landsat study) by quantifying the intersection between polygons of the two types. Second, we estimated the number of false positive settlements by comparing the settlements to huts identified on a high-resolution Bing image. Third, we conducted ground-truthing during a field trip (see Online Resource 1 for details and Fig. 1 for locations visited).

\section{Results}

\section{General increase of inhabited land in the evergreen Delta from 1992 to 2009}

The inhabited area in the evergreen part of the Omo Delta generally grew significantly between 1992 and 2019 for both, dry and rainy season (Fig. 4, for dry season: $\mathrm{P}=0.002$, adjusted $\mathrm{R}^{2}=0.38$ ). Yet, when looking at the data in detail, no clear growth trend is visible between 2009 and 2019 due to strong variations. Accordingly, the observed increase of inhabited land takes place between 1992 and 2009. The interaction terms between dry and wet season do not vary significantly $(\mathrm{P}=0.5)$, indicating that the increase was analogous for both seasons. The inhabited area more than doubled in both cases: in the rainy season we observed an increase from $1.51 \mathrm{~km}^{2}$ (1992) to $4.35 \mathrm{~km}^{2}$ (2019), in the dry season from $2.31 \mathrm{~km}^{2}$ to $5.14 \mathrm{~km}^{2}$. The overall increase is in line with an increase in estimated population in the Dasanech woreda from 22,000 (2000) to 77,000 (2017), extracted from a fully distributed

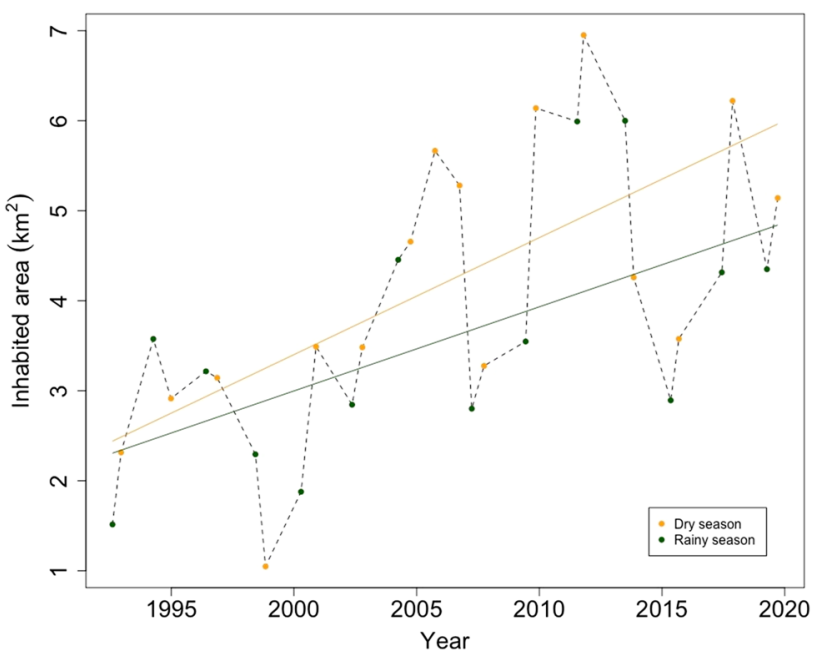

Fig. 4 Growth of inhabited area 1992-2019. The regression lines are displayed in blue (rainy season) and green (dry season). The years 1999, 2006 and 2015 were years with major floods

global population map (Rose et al. 2018). Overall, the inhabited area fluctuates widely over the observed period, ranging from $1.05 \mathrm{~km}^{2}$ (1998) to $6.95 \mathrm{~km}^{2}$ (2011). Fluctuations take place throughout the entire observed time span, over several years, and seasonally. Since 2009, the growth of the inhabited area has stagnated, with the inhabited area fluctuating by approximately $5 \mathrm{~km}^{2}$. The fluctuation indicates population movements at larger scales with the surrounding areas.

\section{Increased persistence of inhabited land in the evergreen Delta from 1992 to 2019}

We observed a growing area of continuously inhabited land along the River arms in the evergreen Delta between 1992 and 2019 (Fig. 5). Traditionally, people only stay for one season at the same place. Since the early 2000 s, however, the continuously inhabited area (occupied in each observation of the five-year interval) has increased fivefold from $0.13 \mathrm{~km}^{2}$ to $0.67 \mathrm{~km}^{2}$ (Table 1). In relation to the average total inhabited area during the relevant time interval, the continuously inhabited part increased from $5 \%$ (1992-1996) to $15 \%$ (2015-2019). This indicates that people increasingly settle in the same place over multiple years. The data include the rainy and dry seasons of each observed year. The continuously inhabited areas are almost exclusively located within $500 \mathrm{~m}$ of the River arms.

\section{Concentration of settlements in the upper Delta from 2009 to 2019}

To understand settlement change in depth since the beginning of large government investments in the region, we 

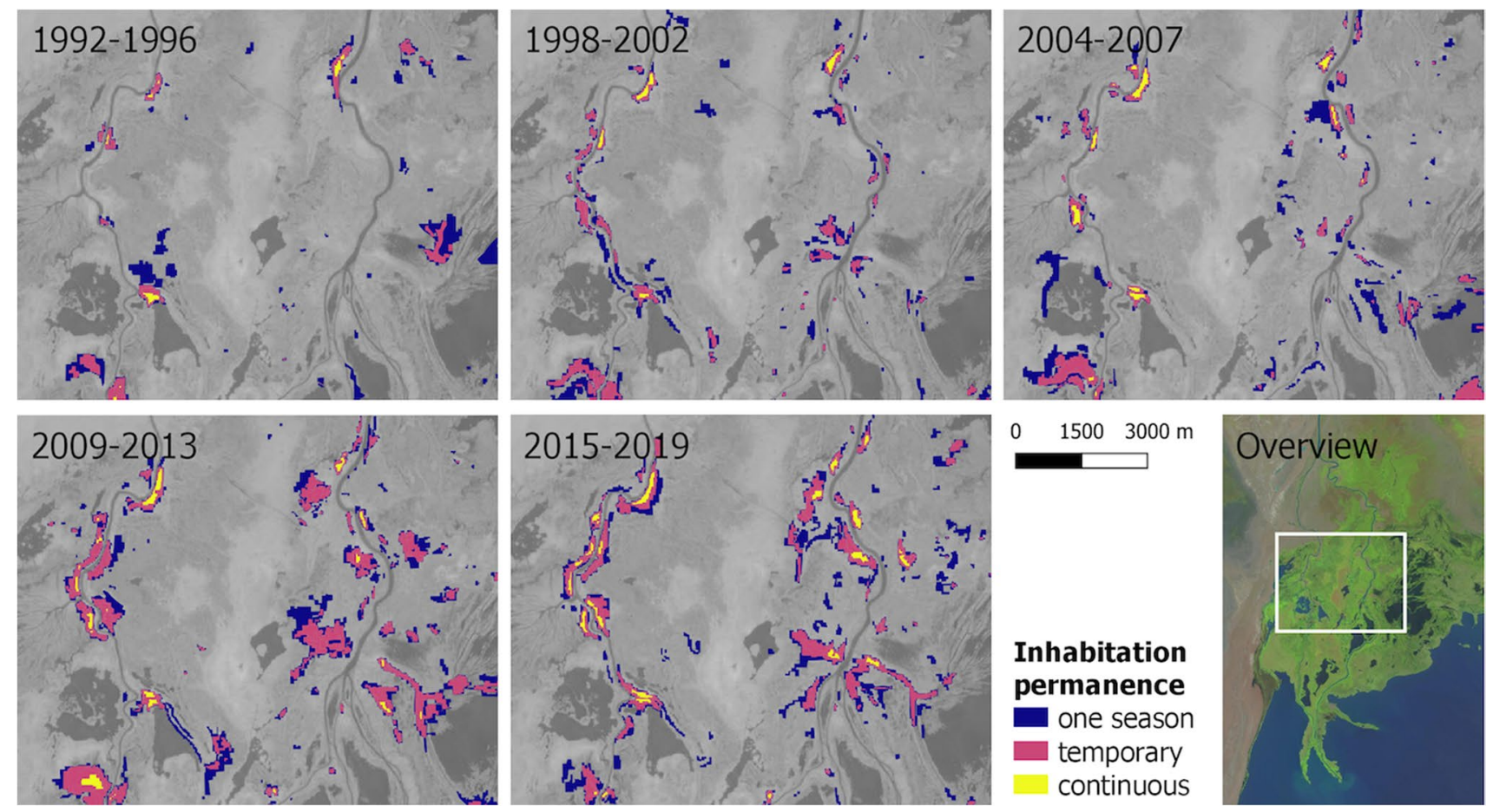

$0 \quad 15003000 \mathrm{~m}$

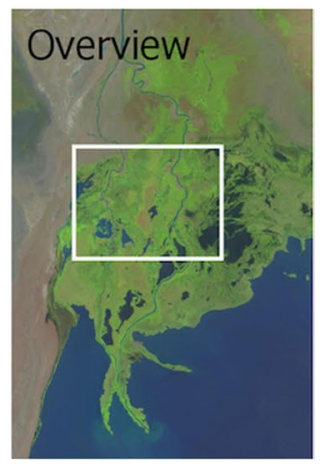

Fig. 5 Observation frequency of inhabited areas in five-year intervals between 1992 and 2019. Each time interval consists of six seasonal measurements, whereby the rainy and dry seasons are included equally

Table 1 Continuously inhabited area (visible during all six observations in the respective time interval) relative to the average total inhabited area

\begin{tabular}{lllc}
\hline Time interval & $\begin{array}{l}\text { Average total } \\
\text { inhabited area } \\
{\left[\mathrm{km}^{2}\right]}\end{array}$ & $\begin{array}{l}\text { Continuously } \\
\text { inhabited area } \\
{\left[\mathrm{km}^{2}\right]}\end{array}$ & $\begin{array}{l}\text { Percent- } \\
\text { age [\%] }\end{array}$ \\
\hline $1992-1996$ & 2.78 & 0.13 & 5 \\
$1998-2002$ & 2.51 & 0.22 & 9 \\
$2004-2007$ & 4.36 & 0.43 & 10 \\
$2009-2013$ & 5.48 & 0.62 & 11 \\
$2015-2019$ & 4.42 & 0.67 & 15 \\
\hline
\end{tabular}

analyzed RapidEye imagery. Since 2009 , we observed a decrease in actual settlement area from $3.93 \mathrm{~km}^{2}$ (2009) to $2.69 \mathrm{~km}^{2}$ (2019). The settlement area in the evergreen Delta decreased notably from $2.39 \mathrm{~km}^{2}$ to $1.1 \mathrm{~km}^{2}$, while the settlement area in the desert plains of the northern Delta remained roughly constant (average of $1.67 \mathrm{~km}^{2}$ ) (Fig. 6). Consequently, the relative share of the settlement area in the desert plains has increased from $39 \%$ (2009) to 59\% (2019).

\section{Increase of tin-roofed houses from 2009 to 2019}

The number of tin-roofed houses in the upper Omo Delta increased rapidly, and from 2009 to 2019 , the number in the study area more than doubled from 71 to 187 houses
(Fig. 7). The increase is continuous, with existing villages, in particular becoming larger. Consequently, most tin roofed houses are found in the northern Delta near to the River arms, while the lower, evergreen part of the Delta is characterized by more traditional-type huts. The locations of the settlements that showed a high population density in 2009 coincide with the occurrence of tin-roofed houses. Until 2015 , the Delta area was accessible only by boat, footpaths, and through tracks accessible with 4-WD. This changed in 2016, when a new paved road was completed to the west of the River (Fig. S1 in Online Resource 1).

\section{Pastoralist population in 2009}

We estimated the mean density of huts per $\mathrm{km}^{2}$ settlement within the desert plains of the Omo Delta in the year 2009 to be 1,945 huts $/ \mathrm{km}^{2}\left(\mathrm{n}=89\right.$, s.e. \pm 147 huts $/ \mathrm{km}^{2}$ ) during the dry season. The range is 138 huts $/ \mathrm{km}^{2}$ to 5,975 huts/ $\mathrm{km}^{2}$. The mean area of a settlement is $0.029 \mathrm{~km}^{2}(\mathrm{n}=89$, s.e. $\pm 0.004 \mathrm{~km}^{2}$ ). Therefore, the average settlement accommodates 56 huts or 280 people. For comparison, Carr (1977) counted a range of two to twenty huts per settlements in her field surveys in the late 1970s. The hut density is greatest along the western River branch respectively in the upper portion of the plains. The extrapolated population in September 2009 was approximately 38,200 people. 
Fig. 6 (a) Location of the settlement polygons in 2009 to 2019 , divided into settlements within the evergreen delta and the northern desert plains based on the leaf area index (LAI) for the dry season of 2016, (b) absolute size of the settlement area in the evergreen delta and the northern desert plain a

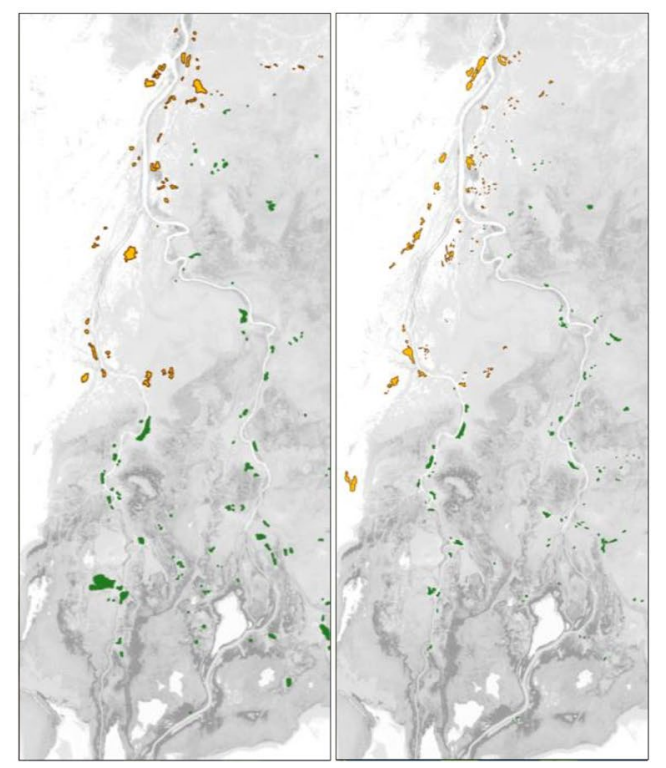

b

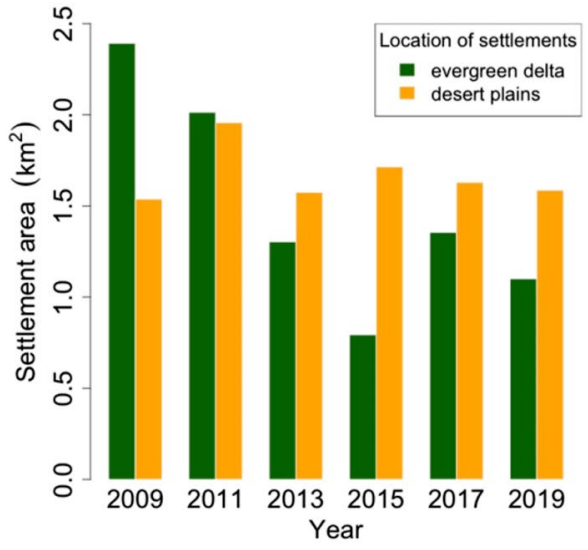

a

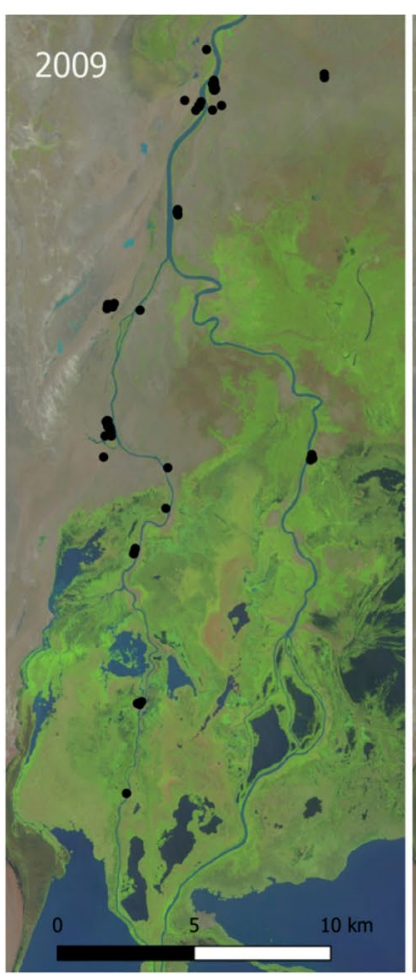

b

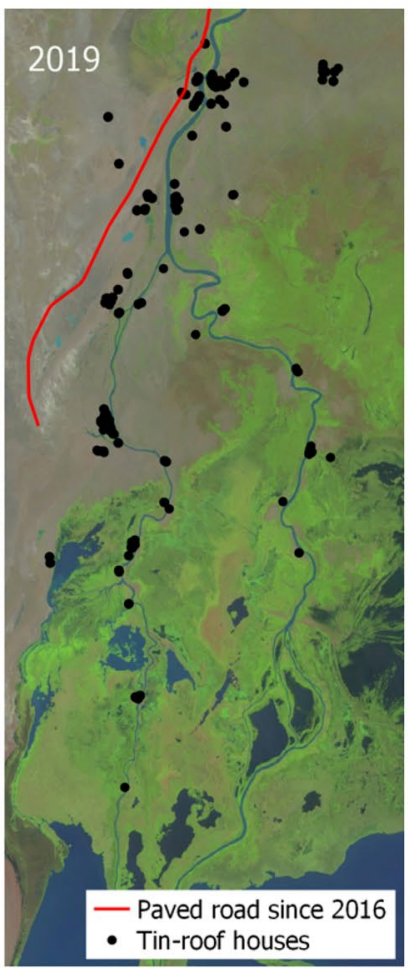

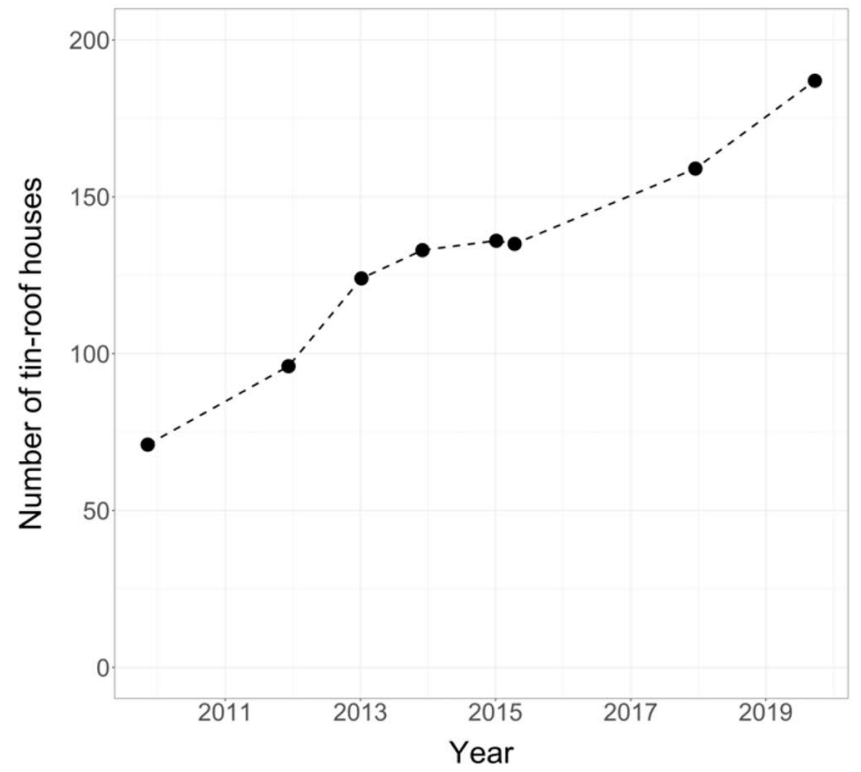

Fig. 7 (a) Geographic distribution of tin-roof houses in 2009 and 2019. The underlying greyscale map is a RapidEye image from September 2019 (Planet Team 2017). (b) Increase in number of tin-roof houses 2009-2019

\section{Accuracy assessment}

The error analysis showed high levels of accuracy in the comparison between mapping of large, inhabited areas
(Landsat study) and settlements (RapidEye study): 82\% of the inhabited area polygons contain an identified settlement $(n=623)$ and analogously, $88 \%$ of the settlement polygons do intersect with inhabited area $(n=780)$. 
However, the accuracy is reduced if we consider the count of polygons and not their area in the calculations $(61 \%$ for Landsat, $72 \%$ for the RapidEye study). This indicates that small areas are prone to mistakes through under-detection. Potential reasons for this discrepancy are that the mapping of small villages is generally difficult due to the low resolution of the imagery, and additionally, deviations are mostly located in the lowermost Delta, which is the area with the most dynamic environment. Comparing our results with high resolution imagery, we identified $92.8 \%$ of the settlement polygons from 2009 to contain huts mapped on the Bing image $(n=97)$. In contrast, $75.4 \%$ of the total huts are located within a settlement $(n=7510)$. This means that we generally determined the settlement area as too small rather than too large. Finally, the ground-truthing confirmed 17 out of 17 settlements to be covered by both the Landsat and the RapidEye analyses. In terms of area coverage, $93 \%$ of the field-mapped settlement area overlapped with the Landsat study and $70 \%$ with the RapidEye study. However, we expect the field-based mapping results to be less accurate than the desk-based high-resolution mapping, due to the physical constraints of drawing precise polygons on a tablet in the field.

\section{Discussion}

We analysed the settlement dynamics of the Delta to inform future river basin management strategies. The findings of our Landsat study highlight the great importance of the Omo Delta for pastoralist peoples. The traditionally nomadic pastoralists are nowadays more dependent on the resources of the Omo Delta than three decades ago. First, our results show that the inhabited land in the Delta more than doubled in size since 1992. This growth trajectory is generally in line with the government's census data (PCC 1994, 2007). Second, we showed not only that there are more people overall in the Delta, but also that they remain in the same place for longer. This is indicated through inhabited areas along the River arms that are increasingly occupied over several years and without seasonal variation. The continuously inhabited areas coincide with areas suitable for flood-recession agriculture (see Fig. 1). While the nomadic way of life is still predominant, permanent settlements are gaining in importance. We attribute our observations to resource scarcity that has forced Dasanech people to live in and near the Delta in the first place. This so-called 'option squeeze' refers to pressures on the traditional livelihood activity of livestock herding that occurred in the past half-century, including prolonged droughts, land restrictions by political forces, and conflicts among competing tribes (see Carr 2017a; Yntiso 2012). Due to these pressures, previously secondary activities such as flood-recession agriculture and fishing became more important for survival and led many Dasanech to relocate towards the Omo River banks and Lake Turkana (Carr 2017a). In sum, the Omo Delta has become the last option for survival for many Dasanech villagers (Carr 2017b), who now depend on the ecosystem services of the Delta and are thus vulnerable to environmental changes.

The Gibe III dam and water abstraction for irrigation agriculture schemes caused a reduction in seasonal floods and may in the future lead to an overall reduction of River flow (Gownaris et al. 2017; Hodbod et al. 2019a). The Dasanech are highly vulnerable to such changes due to their dependency on the Delta's ecosystem services (Carr 2017b). Declining ecosystem services may play a role in Dasanech lifestyle changes: the cessation of seasonal flooding, and thus sediment and nutrient flows, affects the availability of land for livestock grazing and cropland, leading to the collapse of flood-recession agriculture (Hodbod et al. 2019a; Hodbod et al. 2019b). Lake Turkana's predicted fisheries yield is also expected to decline by over two thirds due to the loss of the Lake's seasonal water level oscillations (Gownaris et al. 2017). We have confirmed that floodrecession agriculture and fisheries have become one of the adaptation mechanisms the Dasanech are relying upon (Carr 2017a). Further diversification of livelihoods is necessary as these livelihood strategies are now under threat.

Our data show that the Dasanech have already begun to adapt to the livelihood decline taking place in the Delta. Our Landsat study helped to capture the general growth in the extent of inhabited land in the Delta, but its limitations make it inadequate for capturing settlement changes in detail. In our RapidEye study, we provide a detailed account of the development of pastoral settlements and infrastructure that have taken place since the start of large governmental investments in the region, including the construction of Gibe III. Our results are consistent with previous studies showing that groups are shifting from mobile to more sedentary livelihoods (Carr 2017b; Homewood et al. 2009; Leslie et al. 2013). We observed increasing villagization and concentration of settlements in the northern desert plains of the Delta. Tin-roofed houses more than doubled in number since 2009, which we associate with the establishment of more permanent and dense housing. The houses are densest in the desert plains between Omorate and the evergreen part of the Delta. Fewer tin-roofed houses have been built in the evergreen Delta, where settlement area has halved since 2009. This points to a reduction of temporarily established pastoralist settlements in the wetlands, possibly related to the loss of pasture areas due to the recent wide spread of the invasive shrub Prosopis juliflora (personal observations). In the desert plains, settlement area has remained constant, but the change of building materials indicates that settlement concentrated there. Access to this area has been facilitated by the completion of the paved road in 2016. Our observations 
suggest that people continue to use the Delta as a livelihood resource, but increasingly live in permanent houses outside of the evergreen Delta.

The Ethiopian government's stated goal is to establish permanent settlements and promote irrigated agriculture for pastoralists in response to environmental changes caused by upstream River regulation and water abstraction (Hodbod et al. 2019a). The desert plains, where the concentration of settlements took place, are indeed suitable for irrigated agriculture. There have already been attempts to establish such schemes south of Omorate since the 1970s (see Sternberg and Ahearn 2019; Swart 1998). However, access to irrigation schemes and pasturelands by indigenous communities in the Lower Omo Valley is limited due to cultural, technical, and political constraints (Hodbod et al. 2019a; Kamski 2016). Another explanation for the concentration of settlements in the northern Delta is therefore immigration for the purpose of commercial fishing. Fishing cooperatives sponsored by NGOs and government offices have established settlements in the upper Delta, with larger fishing enterprises located in tin-roofed houses. At local level, this has provided new employment opportunities for youth in towns such as Omorate. On a broader scale, people from other areas in Ethiopia and Kenya are increasingly migrating into the Delta area for commercial fishing and trading (Carr 2017b). The area is a major spot of conflict due to its high fish concentration. Intensifying conflicts in the northern part of Lake Turkana between the Turkana and Dasanech fishers may have accelerated migration to the upper Delta (Carr 2017b; Gownaris et al. 2017). In summary, commercial fishing combined with declining livelihoods could be an important driver of settlement concentration in the upper Delta.

The development of environmental flow (artificial flooding) schemes is vital for the maintenance of the Delta's and Lake Turkana's ecosystem services and therefore for the livelihoods of most pastoralist people living in temporary settlements (African Resources Working Group 2008; Stevenson and Buffavand 2018). Annual flood releases have been recommended in the environmental and social impact assessment for Gibe III (GoE \& EEPC 2009), however, it is unclear how far they have been put in practice. While people continue to be dependent on seasonal floods, more permanent housing close to the River also means that people will be increasingly threatened by extreme floods. Flood mitigation is crucial, because large floods, as occurred in August 2020, become particularly destructive and dangerous if people settle permanently in flood-prone areas (Fig. S2 in Online Resource 1). The trade-off between flood benefits and threats has important implications for the effective management of Gibe III (see, for example, Hoang et al. 2018). We stress the importance of an integrated river basin management plan that can ensure food security for the downstream pastoralist communities while reducing the risk of extreme flooding events. This requires proper coordination and an early warning system that is adapted to the specific locations of Dasanech settlements. The ongoing construction of the new Koysha dam and the large-scale irrigation development of Kuraz sugar should be included in the integrated river basin management plan. For example, integrating the livestock production system with large scale irrigated agriculture is possible (Schlee 2013) and could compensate the loss of dry season grazing areas. Another possibility is the transition to employment in large-scale agricultural projects, as being advocated by the government. This entails major cultural implications (Hodbod et al. 2019a).

Ethiopian pastoralist communities are difficult to study due to, among others, their high mobility over remote terrain (Wild et al. 2019). We estimate the population within the study area at roughly 40,000 people (in 2009). The Ethiopian government estimates the population in the entire Dasanech woreda (about four times the study area) at about 46,000 people (PCC 2007). Consequently, the number of pastoralists affected by recent developments in the region is possibly underestimated by the government. Additionally, indigenous communities with their livelihoods in wetland areas such as the Omo Delta cannot be addressed as one coherent and stable group of landscape users. Rather, social processes, conflicts, and environmental changes form a complex human-environmental system that evolves over time, with settlements being the most visible patterns in the landscape. People have adapted in the past and will adapt in the future to changing circumstances (Dixon 2005; Sobania 2011). The Dasanech are under pressure to further diversify their livelihoods due to the decline of the Delta's vital ecosystem services, and more efforts are needed to make sure no one is left behind (Hailu Woldegebrael 2018). Environmental flows to maintain flood-recession agriculture have been promised by the government of Ethiopia, but the Dasanech leaders have repeatedly complained that the government has not kept this promise (pers. observation). Similarly, although protection against sudden large floods was an argument in favour of the Gibe III dam (Zenawi 2011), this was not guaranteed in 2020. When designing a sustainable river basin management plan, the settlement behaviour of the local community should be taken into consideration. The authorities must then ensure that those affected are actively involved in the decision-making processes to be able to respond to the current ecological and social changes brought about by dams and water abstractions.

\section{Conclusions}

With our detailed account of three decades of settlement dynamics in the Omo Delta we provide another layer of data to existing anthropological studies in a remote and highly 
dynamic wetland environment. The settlement behaviour in the Delta depends on multiple biophysical, cultural, political, and other factors (McPeak and Little 2005) that we are not able to address comprehensively as they require field-based social science approaches (Fox et al. 2019). The applied methodology is clearly top-down and does not account for pastoralist people's motivations, preferences, and interests. Therefore, our approach should not replace direct interaction with the people concerned. Nonetheless, by identifying, quantifying, and mapping settlement dynamics in the Delta, we are giving greater emphasis to people who are directly affected by the environmental changes resulting from river basin development. By determining local settlement patterns, our data help to improve recognition of local populations for future river basin management.

Supplementary Information The online version contains supplementary material available at https://doi.org/10.1007/s10745-021-00257-6.

Acknowledgements This study was funded by the Horizon 2020 programme of the European Union. We thank Nicole Ponta and Jaboury Ghazoul for helpful comments on the manuscript and Amare Bantinder, Bini Z. Tobi, and Gnekumat Asrat for providing valuable insights and support in the field.

Funding Open Access funding provided by ETH Zurich. DAFNE project of the European Union H2020 program (Grant Agreement Number 690268).

Data availability The underlying GIS data is publicly available through the Zenodo repository (https://doi.org/10.5281/zenodo.5092247). A summary of the numerical values of the GIS data is included in Online Resource 1.

\section{Declarations}

Conflict of interest The authors declare that they have no conflict of interest.

Open Access This article is licensed under a Creative Commons Attribution 4.0 International License, which permits use, sharing, adaptation, distribution and reproduction in any medium or format, as long as you give appropriate credit to the original author(s) and the source, provide a link to the Creative Commons licence, and indicate if changes were made. The images or other third party material in this article are included in the article's Creative Commons licence, unless indicated otherwise in a credit line to the material. If material is not included in the article's Creative Commons licence and your intended use is not permitted by statutory regulation or exceeds the permitted use, you will need to obtain permission directly from the copyright holder. To view a copy of this licence, visit http://creativecommons.org/licenses/by/4.0/.

\section{References}

Adams, W. M. (1993). Indigenous use of wetlands and sustainable development in West Africa. The Geographical journal, 159(2), 209-218.
Africa Resources Working Group (2008). Environmental and social impacts of the proposed Gibe III hydroelectric project in Ethiopia's Lower Ome river basin. Missoula, Montana: Department of Geography, University of Montana. http://www.forestpeoples.org/ sites/default/files/publication/2010/08/ethiopiahydroelecimpactsm ay08eng.pdf. Accessed 12/07/2021.

Avery, S. T., \& Tebbs, E. J. (2018). Lake Turkana, major Omo River developments, associated hydrological cycle change and consequent lake physical and ecological change. Journal of Great Lakes Research, 44(6), 1164-1182, https://doi.org/10.1016/j.jglr.2018. 08.014.

Carr, C. J. (1977). Pastoralism in Crisis. The Dasanetch and their Ethiopian Lands. Chicago, Illinois: Department of Geography, University of Chicago.

Carr, C. J. (2017a). Transboundary Survival Systems: A Profile of Vulnerability. In C. J. Carr (Ed.), River Basin Development and Human Rights in Eastern Africa - A Policy Crossroads (pp. 53-74). Cham: Springer International Publishing.

Carr, C. J. (2017b). The Dasanech of the Lowermost Omo Basin: From Adaptation to Development Debacle. In C. J. Carr (Ed.), River Basin Development and Human Rights in Eastern Africa - A Policy Crossroads (pp. 111-144). Cham: Springer International Publishing.

Chapin, M., Lamb, Z., \& Threlkeld, B. (2005). Mapping indigenous lands. Annual Review of Anthropology, 34, 619-638, https://doi. org/10.1146/annurev.anthro.34.081804.120429.

Deleu, J., Franke, J., Gebreslasie, M., \& Linard, C. (2015). Improving AfriPop dataset with settlement extents extracted from RapidEye for the border region comprising South-Africa, Swaziland and Mozambique. Geospatial Health, 10(2), 48-54, https://doi. org/10.4081/gh.2015.336.

Dixon, A. B. (2005). Wetland sustainability and the evolution of indigenous knowledge in Ethiopia. The Geographical journal, 171(4), 306-323, https://doi.org/10.1111/j.1475-4959.2005. 00172.x.

Dwivedi, R. S., Sreenivas, K., \& Ramana, K. V. (2005). Cover: Land-use/ land-cover change analysis in part of Ethiopia using Landsat Thematic Mapper data. International Journal of Remote Sensing, 26(7), 1285-1287, https://doi.org/10.1080/01431160512331337763.

EEA (2019). Copernicus Land Monitoring Service. https://www.coper nicus.eu/en. Accessed 12/07/2021.

FDRoE (2011). Ethiopia's climate-resilient green economy: Green economy strategy. Addis Ababa. https://www.greengrowthknow ledge.org/sites/default/files/downloads/policy-database/ETHIO PIA\% 29\%20Ethiopia\%27s\%20Climate-Resilient\%20Green\% 20Economy\%20-\%20Green\%20Economy\%20Strategy.pdf. Accessed 12/07/2021.

Fox, D. N., Baird, T. D., Stern, M. J., \& Prisley, S. (2019). Where mobile groups settle: Spatial patterns and correlates of Maasai pastoralist sedentarization in Northern Tanzania. Applied Geography, 112, 102086, https://doi.org/10.1016/j.apgeog.2019.102086.

Getahun, A., Wakjira, M., \& Nyingi, D. W. (2020). Social, economic and management status of small-scale fisheries in Omo River Delta and Ethiopian side of Lake Turkana, southern Ethiopia. Ecohydrology \& Hydrobiology, 20(3), 323-332, https://doi.org/ 10.1016/j.ecohyd.2020.05.008.

GoE \& EEPC (2009). Agriconsulting S.P.A., Mid-Day International Consulting, Gibe III Hydroelectric project, level 1 design, environmental and social impact assessment, additional study of downstream impacts. Addis Ababa. https://www.afdb.org/filea dmin/uploads/afdb/Documents/Environmental-and-Social-Asses sments/Gibe\%20III_ESIA\%20Additional\%20Study\%20on\% 20Downstream\%20Impact1_01.pdf. Accessed 12/07/2021.

Gownaris, N. J., Pikitch, E. K., Aller, J. Y., Kaufman, L. S., Kolding, J., Lwiza, K. M. M., et al. (2017). Fisheries and water level 
fluctuations in the world's largest desert lake. Ecohydrology, 10(1), https://doi.org/10.1002/eco.1769.

Haack, B. (1996). Monitoring wetland changes with remote sensing: An East African example. Environmental Management, 20(3), 411-419, https://doi.org/10.1007/Bf01203848.

Hailu Woldegebrael, E. (2018). The Materialization of "Developmental State" in Ethiopia: Insights from the Gibe III Hydroelectric Development Project Regime, Omo Valley. L'Espace Politique. Revue en ligne de géographie politique et de géopolitique, 35, https:// doi.org/10.4000/espacepolitique.4985.

Hathaway, T. (2009). Facing Gibe 3 Dam: Indigenous Communities of Ethiopia's Lower Omo Valley. International Rivers. http://www. archive.nowater-nolife.org/watersheds/omo/hydroReports/2009_ IR_Gibe3_Communities.pdf. Accessed 12/07/2021.

Hoang, L. P., Biesbroek, R., Kummu, M., van Vliet, M. T. H., Leemans, R., Kabat, P., et al. (2018). Managing flood risks in the Mekong Delta: How to address emerging challenges under climate change and socioeconomic developments. Ambio, 47(6), 635-649, https:// doi.org/10.1007/s13280-017-1009-4.

Hodbod, J., Stevenson, E. G. J., Akall, G., Akuja, T., Angelei, I., Bedasso, E. A., et al. (2019a). Social-ecological change in the Omo-Turkana basin: A synthesis of current developments. Ambio, 48(10), 1099-1115, https://doi.org/10.1007/s13280-018-1139-3.

Hodbod, J., Tebbs, E., Chan, K., \& Sharma, S. (2019b). Integrating Participatory Methods and Remote Sensing to Enhance Understanding of Ecosystem Service Dynamics Across Scales. Land, 8(9), 132, https://doi.org/10.3390/land8090132.

Homewood, K., Trench, P. C., \& Kristjanson, P. (2009). Staying Maasai? Pastoral livelihoods, diversification and the role of wildlife in development. In Staying Maasai? (pp. 369-408): Springer.

Human Rights Watch (2012). Ethiopia: Pastoralists Forced off Their Land for Sugar Plantations. https://www.hrw.org/news/2012/ 06/18/ethiopia-pastoralists-forced-their-land-sugar-plantations. Accessed 24/09/2020.

International Hydropower Association (2020). Hydropower Status Report: Sector Trends and Insights. https://hydropower-assets.s3. eu-west-2.amazonaws.com/publications-docs/2020_hydropower_ status_report.pdf. Accessed 12/07/2021.

International Rivers (2020). List of Dam - Threatened World Heritage Sites. https://www.internationalrivers.org/resources/reportsand-publications/list-of-dam-threatened-world-heritage-sites/. Accessed 24/09/2020.

Jaweso, Abate, B., Bauwe, \& Lennartz, B. (2019). Hydro-Meteorological Trends in the Upper Omo-Ghibe River Basin, Ethiopia. Water, 11(9), 1951, https://doi.org/10.3390/w11091951.

Kamski, B. (2016). The Kuraz Sugar Development Project (KSDP) in Ethiopia: between 'sweet visions' and mounting challenges. Journal of Eastern African Studies, 10(3), 568-580, https://doi. org/10.1080/17531055.2016.1267602.

Kamski, B. (2019). Water, sugar, and growth: the practical effects of a 'failed' development intervention in the southwestern lowlands of Ethiopia. Journal of Eastern African Studies, 13(4), 621-641, https://doi.org/10.1080/17531055.2019.1669374.

Khagram, S. (2004). Dams and development: Transnational struggles for water and power. Ithaca, NY: Cornell University Press.

Leslie, P., McCabe, J. T., Bollig, M., Greiner, C., Fratkin, E., Galaty, J. G., et al. (2013). Response diversity and resilience in socialecological systems. Current Anthropology, 54(2), https://doi.org/ $10.1086 / 669563$

McPeak, J., \& Little, P. D. (2005). Cursed if you do, cursed if you don't. In As pastoralists settle (pp. 87-104): Springer.

Micheli, I. (2020). Considering the gender narrative in the mirror of reality. How women consider and manage their right to health in some pastoralist tribes of South Omo Zone (Ethiopia). La Ricerca Folklorica 74, 229-243.
Mitchell, S. A. (2013). The status of wetlands, threats and the predicted effect of global climate change: the situation in Sub-Saharan Africa. Aquatic sciences, 75(1), 95-112, https://doi.org/10.1007/ s00027-012-0259-2.

Müller-Mahn, D., \& Gebreyes, M. (2019). Controversial Connections: The Water-Energy-Food Nexus in the Blue Nile Basin of Ethiopia. Land, 8(9), 135, https://doi.org/10.3390/land8090135.

NASA (2019). Landsat Science. https://landsat.gsfc.nasa.gov/lands at-7/. Accessed 30/12/2019.

Pastoralist Areas Department (2004). Villagization Plan. https://www. mursi.org/documents-and-texts/reports/south-omo-zone-villagizat ion-plan. Accessed 12/07/2021.

PCC (1994). The 1994 Population and Housing Census of Ethiopia: Statistical Report for Southern Nations, Nationalities and Peoples' Region; Part I: Population Size and Characteristics. https://www.statsethiopia.gov.et/wp-content/uploads/2019/06/ Population-and-Housing-Census-1994-SNNPR-Region.pdf. Accessed 12/07/2021.

PCC (2007). The 2007 Population and Housing Census of Ethiopia: Statistical Report for Southern Nations, Nationalities and Peoples' Region; Part I: Population Size and Characteristics. IPUMS project. https://microdata.worldbank.org/index.php/ catalog/2747/related-materials. Accessed 12/07/2021.

Planet Team (2017). Planet Application Program Interface: In Space for Life on Earth. San Francisco, California.

QGIS Development Team (2018). QGIS Geographic Information System. Open Source Geospatial Foundation Project. http:// qgis.osgeo.org. Accessed 12/07/2021.

Riethof, M. (2017). The international human rights discourse as a strategic focus in socio-environmental conflicts: the case of hydroelectric dams in Brazil. The International Journal of Human Rights, 21(4), 482-499, https://doi.org/10.1080/13642987.2016. 1191775.

Rose, A. N., McKee, J. J., Urban, M. L., \& Bright, E. A. (2018). LandScan 2017. Oak Ridge: Oak Ridge National Laboratory.

Sanyal, J., \& Lu, X. X. (2005). Remote sensing and GIS-based flood vulnerability assessment of human settlements: a case study of Gangetic West Bengal, India. Hydrological Processes: An International Journal, 19(18), 3699-3716, https://doi.org/10. 1002/hyp.5852.

Schapper, A., Unrau, C., \& Killoh, S. (2019). Social mobilization against large hydroelectric dams: A comparison of Ethiopia, Brazil, and Panama. Sustainable Development, 28(2), 413-423, https://doi.org/10.1002/sd.1995.

Schlee, G. (2013). Why states still destroy pastoralism and how they can learn that in their own interest they should not. Nomadic Peoples, 17(2), 6-19, https://doi.org/10.3167/np.2013.170203.

Semeria, F. (2020). Modelling the impact of dams on flood recession agriculture in the Omo Valley: a satellite-data based analysis. Milano, Lombardia: Politechnico Milano.

Sobania, N. (2011). The formation of ethnic identity in South Omo: The Dassenech. Journal of Eastern African Studies, 5(1), 195210, https://doi.org/10.1080/17531055.2011.544542.

Sternberg, T., \& Ahearn, A. (2019). Arid Land Systems: Sciences and Societies: MDPI.

Stevenson, E. G. J., \& Buffavand, L. (2018). "Do Our Bodies Know Their Ways?" Villagization, Food Insecurity, and Ill-Being in Ethiopia's Lower Omo Valley. African Studies Review, 61(1), 109-133, https://doi.org/10.1017/asr.2017.100.

Swart, M. F. (1998). The Call of Africa: The Reformed Church in America Mission in the Sub-Sahara, 1948-1998: Wm. B. Eerdmans Publishing.

Syvitski, J. P. M., Kettner, A. J., Overeem, I., Hutton, E. W. H., Hannon, M. T., Brakenridge, G. R., et al. (2009). Sinking deltas due to human activities. Nature Geoscience, 2(10), 681-686, https:// doi.org/10.1038/NGEO629. 
Tebbs, E., Avery, S. T., \& Chadwick, M. (2019). Satellite remote sensing reveals impacts from dam-associated hydrological changes on chlorophyll-a in the world's largest desert lake. River Research and Applications, 36(2), 211-222, https://doi. org/10.1002/rra.3574.

Tessler, Z. D., Vörösmarty, C. J., Grossberg, M., Gladkova, I., Aizenman, H., Syvitski, J. P. M., et al. (2015). Profiling risk and sustainability in coastal deltas of the world. Science, 349(6248), 638-643, https://doi.org/10.1126/science.aab3574

Turton, D. (2018). Hydropower and irrigation development in the Omo Valley. Antropologia Pubblica, 4(1), 51-64, https://doi. org/10.1473/anpub.v4i1.127

U.S. Geological Survey (2019). EarthExplorer. https://earthexplorer. usgs.gov/. Accessed 12/07/2021.

Velpuri, N. M., \& Senay, G. (2012). Assessing the potential hydrological impact of the Gibe III Dam on Lake Turkana water level using multi-source satellite data. Hydrology and Earth System Sciences, 16(10), 3561-3578, https://doi.org/10.5194/hess-16-3561-2012.

Watmough, G. R., Marcinko, C. L. J., Sullivan, C., Tschirhart, K., Mutuo, P. K., Palm, C. A., et al. (2019). Socioecologically informed use of remote sensing data to predict rural household poverty. Proceedings of the National Academy of Sciences, 116(4), 1213-1218, https://doi.org/10.1073/pnas.1812969116.

Wild, H., Glowacki, L., Maples, S., Mejía-Guevara, I., Krystosik, A., Bonds, M. H., et al. (2019). Making Pastoralists Count: Geospatial Methods for the Health Surveillance of Nomadic Populations. The American journal of tropical medicine and hygiene, 101(3), 661-669, https://doi.org/10.4269/ajtmh.18-1009.

Yntiso, G. (2012). Environmental Change, Food Crises and Violence in Dassanech, Southern Ethiopia. In O. S. I. o. P. S. Research Unit Peace and Conflict Studies, Freie Universität Berlin (Ed.), Research Report Peace and Conlict Studies (Vol. 1). Berlin: Freie Universität Berlin, Research Unit Peace and Conflict Studies.

Zenawi, M. (2011). Speech during the 13th Annual Pastorialists' Day celebrations. Jinka, South Omo. http://mursi.org/pdf/Meles\%20Jinka\% 20speech.pdf. Accessed 12/07/2021.

Publisher's Note Springer Nature remains neutral with regard to jurisdictional claims in published maps and institutional affiliations. 